\title{
The Concept of an Energy Self-Sufficient Farm System Compatible with Sustainable Development in a Selected Region in Poland
}

\author{
Jacek Bieranowski, Tomasz Olkowski* \\ Department of Electrical and Power Engineering, Electronics and Automatics, Faculty of Technical Sciences, \\ University of Warmia and Mazury in Olsztyn \\ 11 Oczapowskiego St, 10-736 Olsztyn, Poland
}

Received: 18 May 2015

Accepted: 26 November 2015

\begin{abstract}
This paper analyses the real quantity of organic waste in the Polish province of Warmia and Mazury to determine the degree of farm energy self-sufficiency. Systems engineering methods were used in the performance of the study. A relational and mathematical model was constructed to estimate the energy potential of waste biomass in the selected area. This model is the basis for conducting detailed studies, whose results are presented in the content of the paper.

The constructed model allows the determination of such parameters as:

- The value of the energy potential of organic waste generated by farms in the selected area.

- The value of the technical (real) energy potential of organic waste from farms using specific technologies.

- The type of waste with the highest energy potential.

Our paper defines the concept of the degree of primary energy substitution with renewable energy from agricultural organic waste and presents a methodology for determining the degree of covering the real demand of farms for electrical energy and heat.

A statistical model for estimating the unit energy potential of organic waste from a given farm per 1 ha of area was also developed. This model allowed the total energy potential of organic waste from agriculture to be determined for the studied area. In the studied province, the total energy potential of organic waste from agriculture amounts to $16.74 \mathrm{PJ} \cdot \mathrm{yr}^{-1}$.

Although this study shows that the energy potential contained in organic waste from agriculture is significantly large, it is disregarded by farmers and decision-makers. Focusing on the production of energy crops in order to satisfy the demand for energy biomass distorts the image that emerges from our studies: the level of renewable energy generated only from organic waste makes the idea of energy self-sufficiency of farms appear plausible. We considered only those groups of waste that cannot be used in agriculture.
\end{abstract}

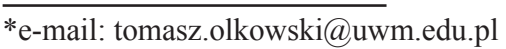


The use of the energy potential of organic waste will permit a significantly high reduction of primary $\mathrm{CO}_{2}$ environmental emissions.

Keywords: energy potential of organic waste from agriculture, mathematical model of the system, degree of energy substitution, energy self-sufficient farm, $\mathrm{CO}_{2}$ reduction

\section{Introduction}

One of basic global actions in the area of energy production is reducing carbon dioxide emissions to the atmosphere by substituting fossil fuels with renewable energy sources, for which carbon dioxide emissions are considered neutral for the environment $[1,2] . \mathrm{CO}_{2}$ emissions into the atmosphere resulting from fossil fuel combustion increased from ca. 3 million tons in 1751 to around 9.7 billion tons in 2012 [3]. Many researchers [411] are of the opinion that the high level of carbon dioxide emissions contributes to climate change, especially to global climate warming.

For reducing primary $\mathrm{CO}_{2}$ air emissions, the use of biomass from agriculture as a renewable energy source holds particularly high promise [10]. Agriculture generates large quantities of waste biomass [11, 12], from which second-generation biofuels can be produced. This will increase the total quantity of biofuels produced sustainably and beneficially to the environment [13-15]. The need to use, e.g., cellulose for bioethanol production was raised by T. Sarchinger [16], who states that the demand for edible plants will rise by ca. $70 \%$ by 2050 . Consequently, energy management of organic waste from agriculture so as not to increase the production area of energy crops at the expense of edible plants acquires special importance. The authors of the paper consider that the energy use of waste biomass from agriculture is currently at a low level, and studies on the subject are at an early stage. Studies of the energy potential of organic waste using index methods can differ widely. For example, globally the energy potential of waste has been estimated at 10-69 $\mathrm{EJ}^{-\mathrm{yr}^{-1}}$ depending on the adopted methodology [1721]. Therefore, we undertook field research to estimate the real potential of organic waste from agriculture in our selected area. Our preliminary study [22] confirmed the possibility of significant substitution of primary energy consumed in agriculture with energy from agricultural waste biomass. These actions will not only reduce greenhouse gas emissions, but will also allow farms to achieve substantial energy self-sufficiency.

As a result of agricultural production intensification, waste biomass is generated in amounts significantly exceeding the possibilities of its use as a natural organic fertilizer. This constitutes a real threat to the environment because of the foul smell, pathogenic compounds, and greenhouse gases [23-25]. Therefore, the use of surplus waste biomass for energy purposes can bring significant benefits such as $[11,12]$ :

- Reducing primary $\mathrm{CO}_{2}$ emissions into the atmosphere by decreasing fossil fuel consumption.
- Improving the energy balance of a particular area.

- Utilizing onerous waste substances.

- Achieving energy self-sufficiency of farms.

This paper seeks answers to the following questions:

- What methods of estimating the energy potential of waste biomass from agriculture should be used?

- How much electrical energy and heat can be produced from organic waste on a farm?

- What type of waste has the highest energy potential?

- To what degree can the energy demand of the representative farm be substituted by using the energy potential contained in organic waste?

- What is the relationship between farm size and the amount of energy that can be produced from organic waste?

- What is the energy potential of waste biomass from agriculture in a single province?

- What benefits to the environment will the use of waste biomass from agriculture for energy production bring?

\section{Material and Methods}

\section{Characteristics of Organic Waste from Agriculture}

Organic waste from farms is solid, semi-solid, or liquid substances that contain plant (e.g., cereal straw, stalks of cultivated plants, weeds, branches from orchard care) and animal residues (e.g., manure, slurry, poultry droppings, bedding, etc.) $[26,27]$.

The main source of waste in the Polish agricultural sector is cereal production, whose basic aim is obtaining grain for animal and poultry feed and for consumption purposes $[28,29]$. The waste in this production is straw, used mainly as bedding in animal breeding and in plant production to improve soil quality [30], as well as in mushroom or vegetable production. According to statistical data, a total of ca. 30 million tons of straw is obtained in Poland annually [28, 31], of which ca. 20 million tons are consumed for the above purposes and the other 10 million tons $(33 \%)$ can be used for energy purposes (for comparison, in Europe, on average, 22\% of cereal straw is available for energy purposes [30]). Assuming that in energy terms $1 \mathrm{~kg}$ of medium-quality coal is equivalent to $1.5 \mathrm{~kg}$ of straw, the energy of $161 \mathrm{TJ}$ (7 million tons of coal) can be obtained from 10 million tons of straw.

Organic wastes from animal production such as manure, slurry, and poultry droppings are mainly used on farms as organic fertilizers, but their excess causes farmyard littering or environmental pollution [27]. These wastes can also be used for the production of high-energy biogas by anaerobic 


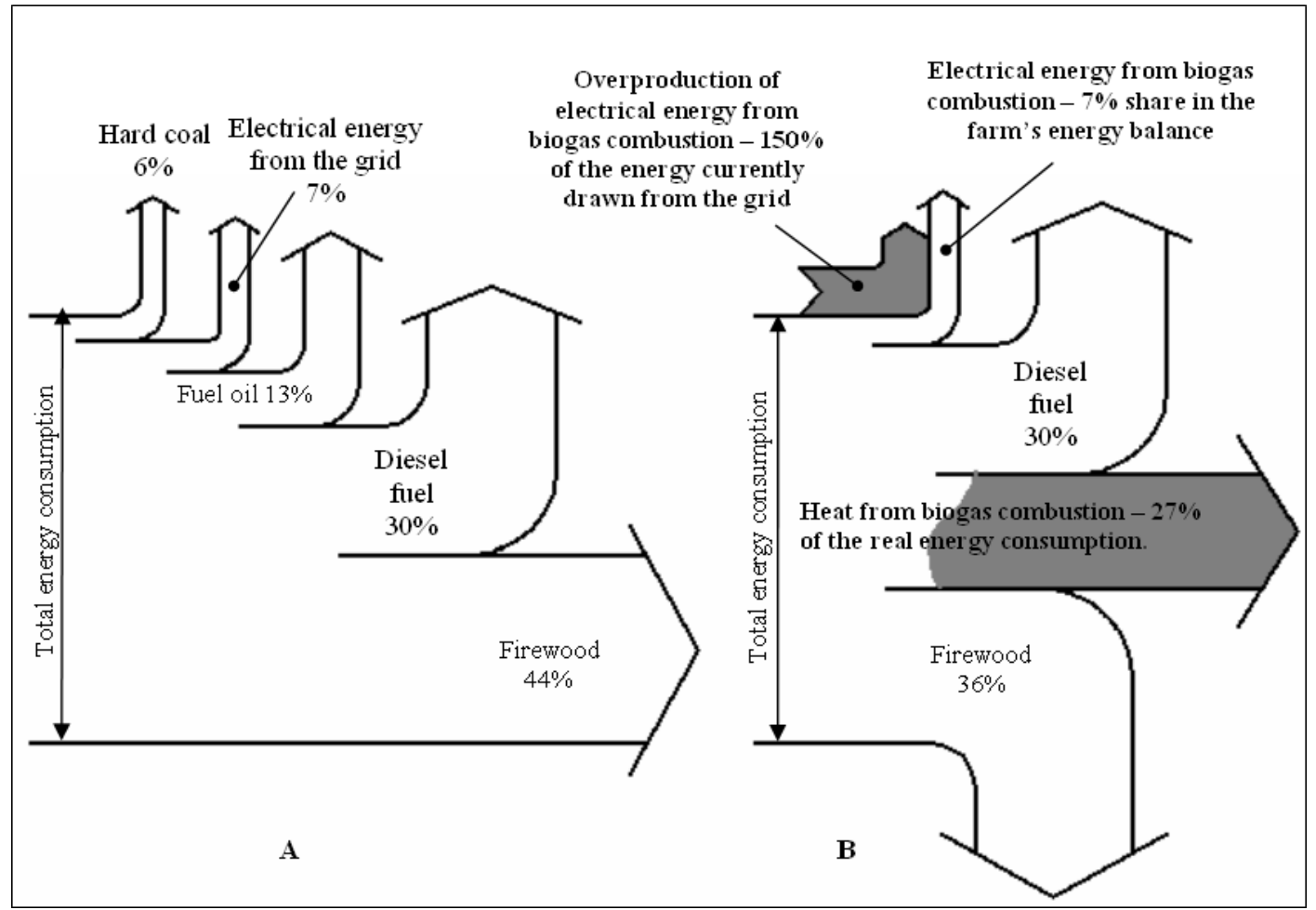

Fig. 1. The energy balance of an individual farm with an area of 39 ha: A - before substitution, B - after primary energy substitution with energy from waste biomass [22].

fermentation [32-34] and the fermentation residue is then applied for soil fertilization [35-38]. Moreover, the application of raw slurry as fertilizer carries many other risks. This substance is characterized extensively in [39], where it was found that excessive raw slurry application usually causes long-term - and sometimes even irreversible - inhibition of biological life in soil and loss of the selfpurification ability of soil.

Excess organic waste can be used for energy production [12, 22, 31, 39, 40]. The energy use of waste from agricultural production can significantly contribute to farms achieving energy self-sufficiency [22].

It was demonstrated that on the representative farm with an area of 39 ha, primary energy could be substituted in the following scope (Fig. 1) [22]:

- Heat from biogas combustion is ca. $27 \%$ of the real consumption of heat from primary carriers, which gives the possibility of complete fuel oil and hard-coal energy substitution as well as partial substitution of another renewable energy carrier, firewood.

- The electrical energy obtained from biogas combustion can fully cover the demand for this type of energy on the studied farm.

- The demonstrated overproduction of electrical energy from biogas combustion can reach ca. $150 \%$ of the energy drawn from the grid, and can be an additional source of farm income.

The energy balance in the form of a Sankey diagram for the above farm is shown in Fig. 1.

\section{Systems Engineering Method}

A systems approach was applied to implement the aim of the paper, represented in systems engineering as a sequence of actions aimed at the creation of an abstract or physical model of the designed empirical system [4146]. The systems modeling process can be divided into the stages $[47,48]$ :

- Identification of the subject system, i.e., any system existing in reality or in the mind which is the subject of research [42, 49, 50].

- Development of the relational model - determination of the set of model elements and its set-theoretic and functional structure as well as the determination of the set of features that characterize individual model elements.

- Development of the mathematical model representation in a mathematical form of the relationships between the values defining the physical structure of the model and its mode of operation [51].

\section{Subject System Identification}

The studied subject system covers farms situated in the province of Warmia and Mazury in northeastern Poland (Fig. 2). It covers an area of 24,192 $\mathrm{km}^{2}$ and has 1.45 million inhabitants (2012). It is the only region in the country that borders the Kaliningrad Oblast of the Russian Federation and it adjoins the waters of the Vistula Lagoon to the northeast. The province capital is the city of Olsztyn with ca. 174,600 inhabitants [52]. 


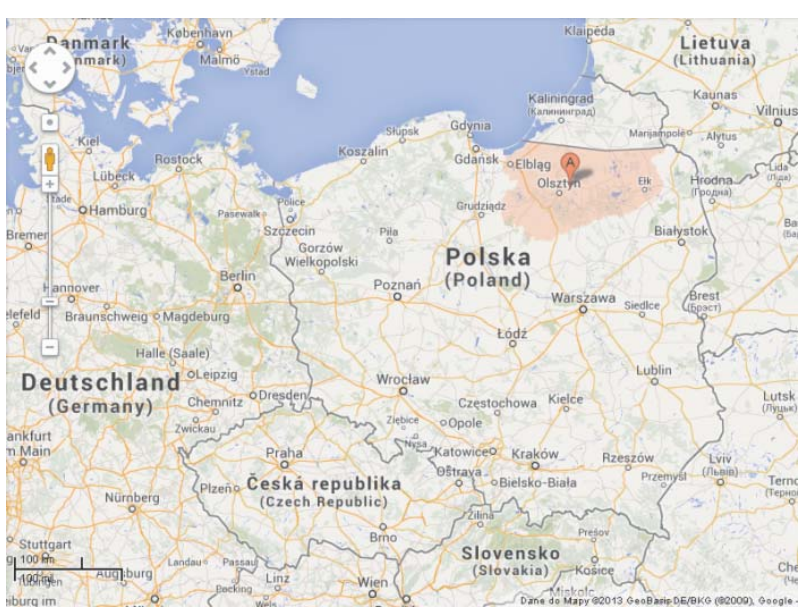

Fig. 2. Location of the province of Warmia and Mazury on the map of Poland [53].

The province is characterized by varied relief, a high diversity of geomorphic forms, and a relatively substantial forest cover. The region lies away from large urban agglomerations and the natural environment is transformed to a very low degree [41]. Due to a significantly shorter vegetation period compared to the other regions of Poland, the climatic conditions are unfavorable for plant production development. However, the conditions for animal production are very good. Despite the mentioned climatic limitations, farms in this region attain a relatively good efficiency compared to other areas of the country. This results mostly from a favorable area structure and relatively low employment [41].

The total number of farms in the region amounts to 65,200 , and the average farm area is $18.74 \mathrm{ha}$-more than twice the mean farm area in Poland [54].

\section{Determination of a Statistically Reliable Sample Size for the Studied Farms}

Farms located in Warmia and Mazury whose area is greater than 10 ha were selected for participation in the study. These farms make up ca. $35 \%$ of the total number of farms in the province and occupy ca. $90 \%$ of the agricultural land area in the analyzed region of Poland. The selection was made based on statistical data analysis [54].

The farm area group selected for the study, with over 10 ha (23,081 farms), makes up ca. $90 \%$ of the agricultural land area in the analyzed region of Poland. The study omitted farms of less than than 10 ha, treating them as unproductive, gradually disappearing farms [55-57].

These farms were divided in the study into agricultural land area groups according to statistical data [54], and the percentage shares were determined for the number of farms from a given group:

- Area group I (10.01-15.00 ha): $32 \%$

- Area group II (15.01-20.00 ha): $20 \%$

- Area group III (20.01-30.00 ha): $20 \%$

- Area group IV (30.01-50.00 ha): 16\%
- Area group V ( $>50.00 \mathrm{ha}): 12 \%$

The representative sampling method was used in this study [58]. One-hundred farms were adopted as the initial sample size. These farms were divided proportionally according to the percentage shares in the area groups. It was assumed that $1 \%$ was one surveyed farm.

The stratified sampling technique was used to select farms for the study [59]. The general population, i.e., farms with an area higher than 10 ha, was divided into strata, which corresponded to the area groups according to [54]. A suitable number of farms was then randomly selected, determined based on their percentage in a given area group. Out of the 23,081 farms, 106 farms were selected for the study.

\section{Abstract Model of the System for Use of Organic Waste from Agriculture for Energy Production}

The model of the system for using organic waste for energy production was created in three stages:

Stage 1: relational model of the subject system

Stage 2: mathematical model created in the set of relations and attributes occurring in the relational model

Stage 3: computations

\section{Relational Model}

The relational model of the system for using organic waste from agriculture for energy production was constructed according to the following four steps:

1. Identification of the subject system's component set.

2. Mapping the component set into the relational model's element set.

3. Identification of relations in the relational model's element set.

4. Identification of the attribute (feature) set of the relational model's elements.

\section{Step 1. Identification of the system's component set}

The component set is the set of all possible factors that influence the system's operation [60]. The system's component set (C) has the form:

$$
C=\left\{c_{i}\right\}_{i=\overline{1,19}}
$$

...where $c_{1}$ is farms, $c_{2}$ is rye straw, $c_{3}$ is rape straw, $c_{4}$ is wheat straw, $c_{5}$ is barley straw, $c_{6}$ is oat straw, $c_{7}$ is triticale straw, $c_{8}$ is maize straw, $c_{9}$ is cereal mixture straw, $c_{10}$ is branches from fruit tree and bush care, $c_{11}$ is branches from forest clearance, $c_{12}$ is pig slurry, $c_{13}$ is cattle slurry, $c_{14}$ is pig manure, $c_{15}$ is cattle manure, $c_{16}$ is poultry droppings, $c_{17}$ is methane fermentation of waste biomass (biogas acquisition), $c_{18}$ is heat from waste biomass combustion, and $c_{19}$ is power and heat cogeneration from combustion of biogas acquired from waste biomass. 


\section{Step 2. Mapping the component set into the relational model's element set}

The subject system was broken down by aggregation of the system's component set into the relational model's element set, keeping the aim of the study in mind. The element set has the final form:

- The components from rye straw $\left(c_{2}\right)$ to cereal mixture straw $\left(c_{9}\right)$ were aggregated into one element, cereal straw $\left(e_{2}\right)$, because of their similar physical properties.

- The component branches from fruit tree and bush care $\left(c_{10}\right)$ and branches from forest clearance $\left(c_{11}\right)$ were aggregated into the common element wood waste from care measures $\left(e_{3}\right)$.

- The components pig $\left(c_{12}\right)$ and cattle slurry $\left(c_{13}\right)$, and pig $\left(c_{14}\right)$ and cattle manure $\left(c_{15}\right)$, were mapped to two model elements (i.e., slurry $\left(e_{4}\right)$ and manure $\left(e_{5}\right)$, respectively); because of the same rates of biogas acquisition from $1 \mathrm{~m}^{3}$ of slurry of these two animal species and the same rates of biogas acquisition from $1 \mathrm{~m}^{3}$ of cattle and pig manure.

As a result of the conducted aggregation, the relational model's element set $(E)$ contains a lower number of elements than the subject system's component set and assumes the form:

$$
E=\left\{e_{i}\right\}_{i=\overline{1,9}}
$$

...where $e_{1}$ is farms, $e_{2}$ is cereal straw, $e_{3}$ is wood waste from care measures, $e_{4}$ is slurry, $e_{5}$ is manure, $e_{6}$ is poultry droppings, $e_{7}$ is methane fermentation, $e_{8}$ is heat from waste biomass combustion, and $e_{9}$ is power and heat cogeneration from combustion of biogas acquired from agricultural waste biomass.

\section{Step 3. Identification of relations in the relational model's element set}

As a result of the analysis of relational connections between the relational model's elements, it was found that two subsystems could be distinguished in the subject system:

- Subsystem of organic waste generation on farms.

- Subsystem of energy production from agricultural organic waste.

The operation of farm $e_{1}$ was assumed in the constructed model. Organic wastes are generated on every farm, which directs energy carriers or is raw material for the production of energy carriers.

The organic waste from agriculture directly suitable for use in energy production by combustion was called dry biomass and includes cereal straw $\left(e_{2}\right)$ and wood waste from care measures $\left(e_{3}\right)$. Dry biomass organic waste can be subjected to upgrading processes, increasing its calorific value by reducing its water content (comminution) and by increasing its density (pelleting).
The organic waste from agriculture characterized in its fresh state by wetness, ascertainable organoleptically, was called wet biomass. Wet waste biomass includes: slurry $\left(e_{4}\right)$, manure $\left(e_{5}\right)$, and poultry droppings $\left(e_{6}\right)$. Energy production from wet waste biomass should be preceded by methane fermentation $\left(e_{7}\right)$, through which an energy carrier is obtained in the form of biogas.

\section{Step 4. Identification of the attribute set of the relational model's elements}

Sets of characteristic attributes $(A)$ of each element of the relational model were distinguished according to the methodology provided in [61] - formula (3). Table 1 presents the distinguished attribute sets for individual model elements.

$$
A=\left\{a_{k}^{i}\right\}_{i=1, k=1}^{I, K}
$$

...where $a_{k}^{i}$ is the $i$ th attribute of the $k$ th element.

The data in Table 1 show that only these attributes of the model elements were distinguished which are consistent with the aim of modeling. This approach allows better organization of the reasoning process during mathematical model construction.

\section{Mathematical Model}

The concept of a mathematical characteristic is introduced in mathematical model construction [47]. The following notation is true for every mathematical characteristic $X_{\psi}$ :

$$
X_{\psi}=f_{\psi}:\{E \cup A\} \rightarrow S_{\left(X_{\psi}\right)}^{M}
$$

...where $E$ is the relational model's element set, $A$ is the attribute set of the relational model's elements, and $S_{\left(X_{\psi}\right)}^{M}$ is the area of the mathematical structure defined by the characteristic $X_{\psi}$.

- The following characteristics $\left(X_{\psi}\right)$ occur in the considered mathematical model:

- Energy potential of dry waste biomass $\left(X_{1}\right)$

- Energy potential of wet waste biomass $\left(X_{2}\right)$

- Technical potential of electrical energy from organic waste $\left(X_{3}\right)$

- Technical potential of heat from organic waste $\left(X_{4}\right)$ Therefore, the set of characteristics can be represented as follows:

$$
X_{\Psi}=\left\{X_{1}, X_{2}, X_{3}, X_{4}\right\}
$$


Table 1. Compilation of distinguished model element attributes.

\begin{tabular}{|c|c|c|}
\hline $\begin{array}{l}\text { Element } \\
\text { name }\end{array}$ & $\begin{array}{c}\text { Element } \\
\text { symbol }\end{array}$ & Attributes \\
\hline Farm & $e_{1}$ & $\begin{array}{l}a_{e l}^{1}-\text { farm no., } \\
a_{e l}^{2}-\text { farm area }[\text { ha }] \\
A_{e l}=\left\langle a_{e 1}^{1}, a_{e l}^{2}\right\rangle\end{array}$ \\
\hline Cereal straw & $e_{2}$ & $\begin{array}{l}a_{e 2}^{1}-\text { available cereal straw mass }\left[\mathrm{kg} \cdot \mathrm{yr}^{-1}\right] \\
a_{e 2}^{2}-\text { calorific value of cereal straw }\left[\mathrm{MJ}^{\mathrm{kg}} \mathrm{kg}^{-1}\right] \\
\qquad A_{e 2}=\left\langle a_{e 2}^{1}, a_{e 2}^{2}\right\rangle\end{array}$ \\
\hline $\begin{array}{l}\text { Wood waste } \\
\text { from care } \\
\text { measures }\end{array}$ & $e_{3}$ & $\begin{array}{l}a_{e 3}^{1}-\text { available wood waste mass }\left[\mathrm{kg} \cdot \mathrm{yr}^{-1}\right] \\
a_{e 3}^{2}-\text { calorific value of wood }\left[\mathrm{MJ} \cdot \mathrm{kg}^{-1}\right] \\
\qquad A_{e 3}=\left\langle a_{e 3}^{1}, a_{e 3}^{2}\right\rangle\end{array}$ \\
\hline Slurry & $e_{4}$ & $\begin{array}{l}a_{e 4}^{1}-\text { available slurry volume }\left[\mathrm{m}^{3} \cdot \mathrm{yr}^{-1}\right] \\
a_{e 4}^{1}-\text { theoretical efficiency of biogas production from } 1 \mathrm{~m}^{3} \text { of slurry }\left[\mathrm{m}^{3}{ }_{\text {biogas }} \cdot \mathrm{m}^{-3} \text { slurry }\right] \\
\qquad A_{e 4}=\left\langle a_{e 4}^{1}, a_{e 4}^{2}\right\rangle\end{array}$ \\
\hline Manure & $e_{5}$ & 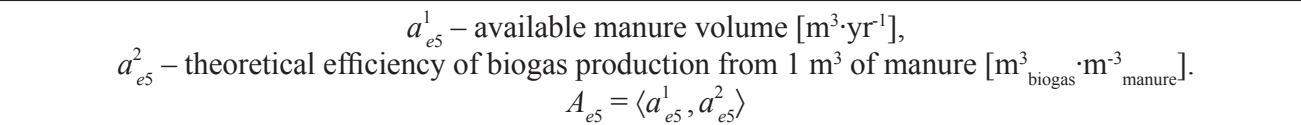 \\
\hline $\begin{array}{l}\text { Poultry } \\
\text { droppings }\end{array}$ & $e_{6}$ & $\begin{array}{l}a_{e 6}^{1}-\text { available mass of poultry droppings }\left[\mathrm{kg} \cdot \mathrm{yr}^{-1}\right], \\
a_{e 6}^{2}-\text { theoretical efficiency of biogas production from } 1 \mathrm{~kg} \text { of poultry droppings }\left[\mathrm{m}^{3}{ }_{\text {biogas }} \cdot \mathrm{kg}^{-1}{ }_{\text {poultry droppings }}\right] \text {. } \\
A_{e 6}=\left\langle a_{e 6}^{1}, a_{e 6}^{2}\right\rangle\end{array}$ \\
\hline $\begin{array}{l}\text { Methane } \\
\text { fermentation } \\
\text { of waste } \\
\text { biomass }\end{array}$ & $e_{7}$ & $\begin{array}{l}a_{e 7}^{1}-\text { efficiency of biogas production from agricultural waste biomass }\left[\mathrm{m}^{3} \cdot \mathrm{yr}^{-1}\right], \\
a_{e 7}^{2}-\text { calorific value of biogas }\left[\mathrm{MJ} \cdot \mathrm{m}^{-3}\right] \\
a_{e 7}^{3}-\text { energy demand of facilities for biogas production from waste biomass }\left[\mathrm{MJ}^{-} \mathrm{yr}^{-1}\right] . \\
\qquad A_{e 7}=\left\langle a_{e 7}^{1}, a_{e 7}^{2}, a_{e 7}^{3}\right\rangle\end{array}$ \\
\hline $\begin{array}{l}\text { Heat from } \\
\text { waste } \\
\text { biomass } \\
\text { combustion }\end{array}$ & $e_{8}$ & $\begin{array}{l}a_{e 8}^{1}-\text { consumption of energy carriers produced from waste biomass }\left[\mathrm{kg} \cdot \mathrm{yr} \mathrm{r}^{-1}\right] \\
a_{e 8}^{2}-\text { efficiency of heat production from combustion of energy carriers produced from waste biomass, } \\
\qquad a_{e 8}^{3}-\text { amount of produced heat }\left[\mathrm{MJ}^{\mathrm{y}} \cdot \mathrm{yr}^{-1}\right] \\
\qquad A_{e 8}=\left\langle a_{e 8}^{1}, a_{e 8}^{2}, a_{e 8}^{3}\right\rangle\end{array}$ \\
\hline $\begin{array}{l}\text { Power } \\
\text { and heat } \\
\text { cogeneration } \\
\text { from biogas } \\
\text { combustion }\end{array}$ & $e_{9}$ & 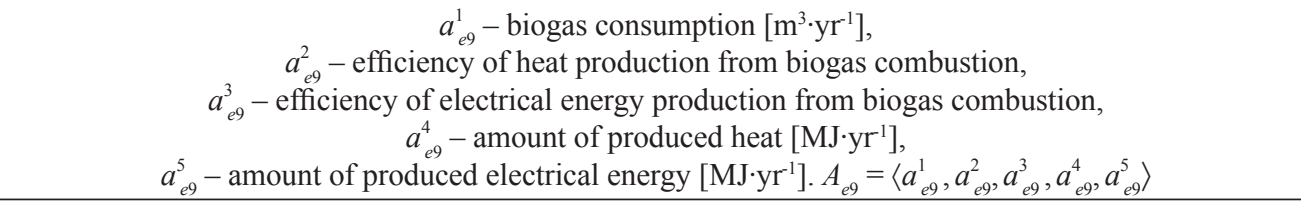 \\
\hline
\end{tabular}

The characteristic $X_{1}$ - energy potential of dry waste biomass - includes:

$$
Q_{1}=Q_{2}+Q_{3}
$$

...where $Q_{1}$ is the energy potential of dry waste biomass $\left[\mathrm{MJ} \cdot \mathrm{yr}^{-1}\right], Q_{2}$ is the energy potential of cereal straw $\left[\mathrm{MJ} \cdot \mathrm{yr}^{-1}\right]$, and $Q_{3}$ is the energy potential of wood waste from care measures $\left[\mathrm{MJyr}^{-1}\right]$

$$
Q_{2}=a_{e 2}^{1} a_{e 2}^{2}
$$

...where $a_{e 2}^{1}$ is cereal straw mass $\left[\mathrm{kg} \cdot \mathrm{yr}^{-1}\right]$ and $a_{e 2}^{2}$ is the calorific value of cereal straw $\left[\mathrm{MJ} \cdot \mathrm{kg}^{-1}\right]$.

$$
Q_{3}=a_{e 3}^{1} a_{e 3}^{2}
$$

...where $a_{e 3}^{1}$ is the mass of wood waste from care measures $\left[\mathrm{kg} \cdot \mathrm{yr}^{-1}\right]$ and $a_{e 3}^{2}$ is the calorific value of wood $\left[\mathrm{MJ} \cdot \mathrm{kg}^{-1}\right]$.
The characteristic $X_{2}$ - energy potential of wet waste biomass - includes:

$$
Q_{4}=Q_{5}+Q_{6}+Q_{7}
$$

...where $Q_{4}$ is the energy potential of wet waste biomass $\left[\mathrm{MJ} \cdot \mathrm{yr}^{-1}\right], Q_{5}$ is the energy potential of slurry $\left[\mathrm{MJ} \cdot \mathrm{yr}^{-1}\right], Q_{6}$ is the energy potential of manure $\left[\mathrm{MJ} \cdot \mathrm{yr}^{-1}\right]$, and $Q_{7}$ is the energy potential of poultry droppings $\left[\mathrm{MJ}^{\circ} \mathrm{yr}^{-1}\right]$.

$$
Q_{5}=a_{e 4}^{1} a_{e 4}^{2} a_{e 7}^{2}
$$

...where $a_{e 4}^{1}$ is slurry volume $\left[\mathrm{m}^{3} \cdot \mathrm{yr}^{-1}\right], a_{e 4}^{2}$ is the rate of biogas acquisition from $1 \mathrm{~m}^{3}$ of slurry $\left[\mathrm{m}^{3}{ }_{\text {biogas }} \cdot \mathrm{m}^{-3}\right.$ slurry $]$, and $a_{e 7}^{2}$ is the calorific value of biogas $\left[\mathrm{MJ} \cdot \mathrm{m}^{-3}\right]$.

$$
Q_{6}=a_{e 5}^{1} a_{e 5}^{2} a_{e 7}^{2}
$$

...where $a_{e 5}^{1}$ is manure volume $\left[\mathrm{m}^{3} \cdot \mathrm{yr}^{-1}\right]$ and $a_{e 5}^{2}$ is the rate of biogas acquisition from $1 \mathrm{~m}^{3}$ of manure $\left[\mathrm{m}^{3}{ }_{\text {biogas }} \cdot \mathrm{m}^{-3}{ }_{\text {manure }}\right]$. 


$$
Q_{7}=a_{e 6}^{1} a_{e 6}^{2} a_{e 7}^{2}
$$

...where $a_{e 6}^{1}$ is the mass of poultry droppings $\left[\mathrm{kg} \cdot \mathrm{yr}^{-1}\right]$ and $a_{e 6}^{2}$ is the rate of biogas acquisition from $1 \mathrm{~kg}$ of poultry droppings $\left[\mathrm{m}^{3}\right.$ biogas $\mathrm{kg}^{-1}$ poultry droppings $]$.

The characteristic $X_{3}$ - technical potential of electrical energy from organic waste - includes:

$$
Q_{8}=Q_{9}
$$

...where $Q_{8}$ is the technical potential of electrical energy from organic waste $\left[\mathrm{MJ} \cdot \mathrm{yr}^{-1}\right]$ and $Q_{9}$ is electrical energy from combustion of biogas acquired from wet waste biomass in a gas-fuelled cogeneration system [MJ.yr ${ }^{-1}$.

$$
Q_{9}=Q_{4} a_{e 9}^{3}
$$

...where $a_{e 9}^{3}$ is the efficiency of electrical energy production in a gas-fuelled cogeneration system.

The characteristic $X_{4}$ - technical potential of heat from organic waste - includes:

$$
Q_{10}=Q_{11}+Q_{12}
$$

...where $Q_{10}$ is the technical potential of heat from organic waste $\left[\mathrm{MJ} \cdot \mathrm{yr}^{-1}\right], Q_{11}$ is heat from dry biomass combustion $\left[\mathrm{MJ} \cdot \mathrm{yr}^{-1}\right]$, and $Q_{12}$ is heat from combustion of biogas acquired from wet biomass in a gas-fuelled cogeneration system $\left[\mathrm{MJ} \cdot \mathrm{yr}^{-1}\right]$.

$$
Q_{11}=Q_{1} a_{e 8}^{2}
$$

...where $a_{e 8}^{2}$ is the efficiency of the solid fuel water heater.

$$
Q_{12}=Q_{4} a_{e 9}^{2}
$$

...where $a_{e 9}^{2}$ is the efficiency of heat production in a gasfueled cogeneration system.

The mathematical model of the system is the basis for determining the energy potential of organic waste from agriculture.

\section{Degree of Primary Energy Substitution with Energy from Agricultural Organic Waste}

The determination of the degree of energy substitution consists in determining the technical energy potential of organic waste from agriculture and its comparison to the value of the real energy consumption on a given farm. The real energy consumption was divided into electrical energy $\left(Q_{c}^{e l}\right)$ and heat $\left(Q_{c}^{t h}\right)$. The following relationships were used to compute the substitution degree:

- Degree of electrical energy substitution $\left(\eta_{s}^{e l}\right)$ :

$$
\eta_{s}^{e l}=\frac{Q_{r}^{e l}}{Q_{c}^{e l}} \cdot 100
$$

- Degree of heat substitution $\left(\eta_{s}^{\text {th }}\right)$ :

$$
\eta_{s}^{t h}=\frac{Q_{r}^{t h}}{Q_{c}^{t h}} \cdot 100
$$

...where:

$\eta_{s}^{e l} \wedge \eta_{s}^{\text {th }} \in(0,1\rangle$ when the amount of electrical energy $Q_{r}^{e l}$ and heat $Q_{r}^{\text {th }}$ from organic waste is lower than or equal to the real energy consumption on the farm $\left(Q_{c}^{e l}, Q_{c}^{t h}\right)$, and $\eta_{s}^{e l} \wedge \eta_{s}^{\text {th }} \in(1, \infty)$ when the amount of electrical energy $Q_{r}^{e l}$ and heat $Q_{r}^{\text {th }}$ from organic waste is greater than the real energy consumption on the farm $\left(Q_{c}^{e l}, Q_{c}^{t h}\right)$.

\section{Research}

\section{Questionnaire Survey Methodology}

The questionnaire survey was carried out on farms in Warmia and Mazury. To implement the set aims of the paper, it was necessary to collect data directly from farm owners. The aim of the questionnaire survey was to collect data on the structure:

- ... and amount of generated organic waste;

- $\quad \ldots$ and size of plant production;

- ... and size of animal production;

- ... and size of the consumption of energy carriers, including electrical energy drawn from the grid.

To conduct the survey we used the diagnostic poll method, well-known and widely applied in social science and which serves to detect different phenomena and show their structural and functional attributes [62, 63]. The diagnostic poll methodology assumes, among other things, the use of the questionnaire interview technique [64]. The farm survey questionnaire was constructed according to the methodology provided in [65].

\section{Questionnaire Survey Results}

\section{Structure of Agricultural Production on the Surveyed Farms}

The structure of agricultural production on the surveyed farms was divided into plant production and animal production and presented synthetically in Table 2 .

As shown in Table 2, in plant production, meadows and pastures are characterized by the largest total cultivation area on the surveyed farms. This is connected with conducted animal production, dominated by cattle production. 
Table 2. Structure of agricultural production on the surveyed farms.

\begin{tabular}{|c|c|c|c|c|c|c|c|}
\hline Products & Meas. unit & $\begin{array}{c}\mathrm{I} \\
10.01- \\
15.00 \text { ha }\end{array}$ & $\begin{array}{c}\text { II } \\
15.01-20.00 \\
\text { ha }\end{array}$ & $\begin{array}{c}\text { III } \\
20.01-30.00 \\
\text { ha }\end{array}$ & $\begin{array}{c}\text { IV } \\
30.01-50.00 \\
\text { ha }\end{array}$ & $\begin{array}{c}\mathrm{V} \\
>50.00 \text { ha }\end{array}$ & TOTAL \\
\hline \multicolumn{8}{|c|}{ PLANT PRODUCTION } \\
\hline rye & ha $\cdot \mathrm{yr}^{-1}$ & 9.70 & 25.20 & 22.00 & 20.40 & 10.00 & 87.30 \\
\hline rape & ha. $y r^{-1}$ & - & - & 4.50 & 16.00 & 16.00 & 36.50 \\
\hline wheat & ha.yr $r^{-1}$ & 8.40 & 7.50 & 29.75 & 42.30 & 81.50 & 169.45 \\
\hline barley & ha.yr $r^{-1}$ & 3.50 & 6.00 & 22.50 & 11.70 & 37.00 & 80.70 \\
\hline oats & ha $\cdot \mathrm{yr}^{-1}$ & 24.20 & 20.10 & 30.50 & 25.50 & 42.50 & 142.80 \\
\hline triticale & ha $\cdot \mathrm{yr}^{-1}$ & 53.95 & 23.30 & 42.35 & 60.76 & 119.50 & 299.86 \\
\hline maize & ha $\cdot \mathrm{yr}^{-1}$ & 14.50 & 9.00 & 9.40 & 30.40 & 73.00 & 136.30 \\
\hline cereal mixtures & ha $\cdot \mathrm{yr}^{-1}$ & 37.68 & 39.70 & 38.00 & 44.30 & 52.50 & 212.18 \\
\hline orchards & ha $\cdot \mathrm{yr}^{-1}$ & 0.10 & 0.70 & 1.15 & 3.43 & 1.05 & 6.43 \\
\hline meadows and pastures & ha $\cdot \mathrm{yr}^{-1}$ & 233.44 & 167.50 & 192.37 & 280.45 & 237.50 & 1111.26 \\
\hline forests & $\mathrm{ha} \cdot \mathrm{yr}^{-1}$ & 2.00 & - & 6.00 & 9.00 & 0.20 & 17.20 \\
\hline root crops & ha $\cdot \mathrm{yr}^{-1}$ & 10.20 & 2.00 & 1.00 & 0.20 & - & 13.40 \\
\hline \multicolumn{8}{|c|}{ ANIMAL PRODUCTION } \\
\hline cattle & $\mathrm{LU} \cdot \mathrm{yr}^{-1}$ & 393.150 & 283.100 & 522.900 & 684.150 & 712.100 & 2595.400 \\
\hline pigs & $\mathrm{LU} \cdot \mathrm{yr}^{-1}$ & 55.500 & 110.400 & 147.300 & 39.600 & 273.000 & 625.800 \\
\hline horses & $\mathrm{LU} \cdot \mathrm{yr}^{-1}$ & 6.000 & 6.000 & 12.000 & 3.600 & - & 27.600 \\
\hline poultry & $\mathrm{LU} \cdot \mathrm{yr}^{-1}$ & 2.988 & 2.292 & 0.688 & 0.764 & 0.584 & 7.316 \\
\hline
\end{tabular}

The reason for such a high intensity of cattle production in the province of Warmia and Mazury is special natural conditions. The region is one of the coldest regions in Poland and ranks among the areas with the shortest growing season in the country, which is confirmed by the study results [66].
Because of the above-mentioned unfavorable conditions for cultivation, animal and (especially) dairy cattle breeding developed, which is economically conditioned because milk purchase prices are subject to lower fluctuations than slaughter animal purchase prices, as shown by statistical data [67-72].

Table 3. Consumption of individual energy carriers on the surveyed farms with breakdown into area groups.

\begin{tabular}{|c|c|c|c|c|c|c|c|}
\hline \multirow[b]{2}{*}{$\begin{array}{l}\text { Energy sources used } \\
\text { on the surveyed farms }\end{array}$} & \multicolumn{5}{|c|}{ Energy content in consumed carriers, by area groups $\left[\mathrm{GJ} \cdot \mathrm{yr}^{-1}\right]$} & \multirow[b]{2}{*}{$\begin{array}{c}\text { Total } \\
{\left[\mathrm{GJ} \cdot \mathrm{yr}^{-1}\right]}\end{array}$} & \multirow[b]{2}{*}{$\begin{array}{l}\text { Average per farm } \\
{\left[\mathrm{GJ} \cdot \mathrm{yr}^{-1} \cdot \text { farm }^{-1}\right]}\end{array}$} \\
\hline & $\begin{array}{c}\mathrm{I} \\
10.01-15.00 \\
\text { ha }\end{array}$ & $\begin{array}{c}\text { II } \\
15.01-20.00 \\
\text { ha }\end{array}$ & $\begin{array}{c}\text { III } \\
20.01-30.00 \\
\text { ha }\end{array}$ & $\begin{array}{c}\text { IV } \\
30.01-50.00 \\
\text { ha }\end{array}$ & $\begin{array}{c}\mathrm{V} \\
>50.00 \text { ha }\end{array}$ & & \\
\hline Electrical energy & 677.47 & 389.80 & 639.01 & 627.53 & 391.68 & $2,725.49$ & 25.71 \\
\hline Hard coal & $1,083.60$ & 526.75 & $1,234.10$ & 496.65 & 722.40 & $4,063.50$ & 38.33 \\
\hline Coke & - & - & 91.50 & 45.75 & - & 137.25 & - \\
\hline Propane/butane gas & 113.01 & 113.85 & 172.00 & 82.93 & 67.78 & 549.57 & 5.18 \\
\hline Fuel oil & 11.64 & - & - & - & - & 11.64 & - \\
\hline Diesel fuel & $1,697.54$ & $1,310.19$ & $1,884.96$ & $2,506.14$ & $2,856.00$ & $10,254.83$ & 96.74 \\
\hline Petrol & 709.80 & 247.98 & 302.25 & 91.81 & 185.25 & $1,537.09$ & 14.50 \\
\hline Firewood & $4,623.69$ & $3,965.03$ & $5,216.38$ & $4,063.63$ & $2,797.05$ & $20,665.78$ & 194.96 \\
\hline
\end{tabular}




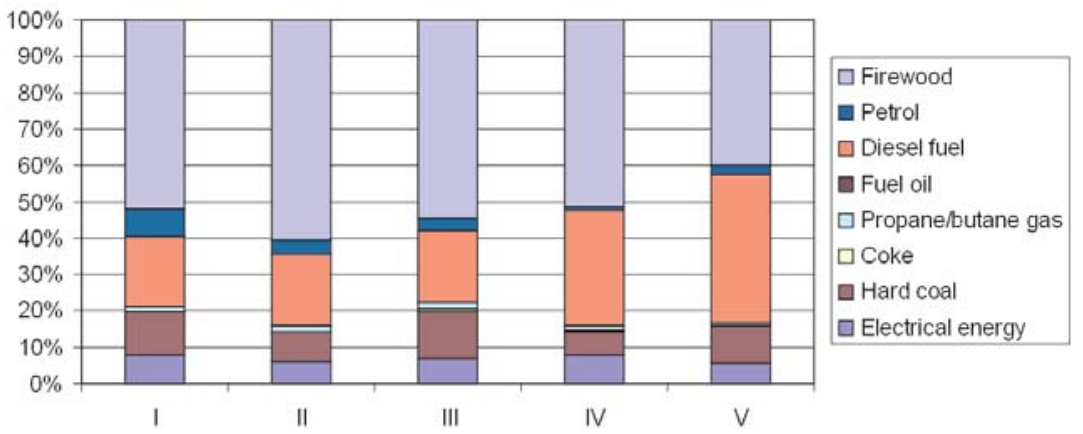

Fig. 3. Percentage share of energy carrier consumption in individual area groups: I - 10.01-15.00 ha, II - 15.01-20.00 ha, III - 20.0130.00 ha, IV - 30.01-50.00 ha, V - more than 50.00 ha.

\section{Structure of Energy Consumption on the Surveyed Farms}

The structure of energy carrier consumption on the surveyed farms, including electrical energy drawn from the grid, is shown in Table 3. The energy potential [GJ $\cdot \mathrm{yr}^{-1}$ ] of all energy sources used on these farms is presented to standardize survey results. The consumption values for individual energy carriers are presented synthetically for the respective farm area groups. The results of research from Table 3 are illustrated in Fig. 3.

Table 4. Structure of organic waste from agriculture generated in individual area groups of the surveyed farms, including denotations from the system's relational model.

\begin{tabular}{|c|c|c|c|c|c|c|c|}
\hline \multirow[b]{2}{*}{ Waste type } & \multirow[b]{2}{*}{$\begin{array}{c}\text { Meas. } \\
\text { unit }\end{array}$} & \multicolumn{5}{|c|}{ Area groups } & \multirow[b]{2}{*}{ Total } \\
\hline & & $\begin{array}{c}\text { I } \\
\begin{array}{c}10.01-15.00 \\
\text { ha }\end{array}\end{array}$ & $\begin{array}{c}\text { II } \\
15.01-20.00 \\
\text { ha }\end{array}$ & $\begin{array}{c}\text { III } \\
20.01-30.00 \\
\text { ha }\end{array}$ & $\begin{array}{c}\text { IV } \\
30.01-50.00 \\
\text { ha }\end{array}$ & $\begin{array}{c}\mathrm{V} \\
>50.00 \text { ha }\end{array}$ & \\
\hline Rye straw $\left(c_{2}\right)$ & $\mathrm{kg}$ & $9,150.00$ & $10,200.00$ & $3,000.00$ & $7,500.00$ & 500.00 & $30,350.00$ \\
\hline Rape straw $\left(c_{3}\right)$ & $\mathrm{kg}$ & - & - & $9,000.00$ & - & - & $9,000.00$ \\
\hline Wheat straw $\left(c_{4}\right)$ & $\mathrm{kg}$ & - & $4,000.00$ & $5,000.00$ & $19,000.00$ & $84,300.00$ & $112,300.00$ \\
\hline Barley straw $\left(c_{5}\right)$ & $\mathrm{kg}$ & - & $1,700.00$ & - & - & $6,500.00$ & $8,200.00$ \\
\hline Oat straw $\left(c_{6}\right)$ & $\mathrm{kg}$ & - & $10,800.00$ & $3,000.00$ & $12,500.00$ & $59,500.00$ & $85,800.00$ \\
\hline Triticale straw $\left(c_{7}\right)$ & $\mathrm{kg}$ & $11,878.00$ & $9,800.00$ & 200.00 & $23,100.00$ & $43,200.00$ & $88,178.00$ \\
\hline Maize straw $\left(c_{8}\right)$ & $\mathrm{kg}$ & $4,375.00$ & - & - & - & - & $4,375.00$ \\
\hline Cereal mixture straw $\left(c_{9}\right)$ & $\mathrm{kg}$ & $3,599.50$ & - & - & - & $20,000.00$ & $23,599.50$ \\
\hline Cereal straw $\left(e_{2}\right)$ & $\mathrm{kg}$ & $29,002.50$ & $36,500.00$ & $20,200.00$ & $62,100.00$ & $214,000.00$ & $361,802.50$ \\
\hline $\begin{array}{l}\text { Branches from fruit tree and } \\
\text { bush care }\left(c_{10}\right)\end{array}$ & $\mathrm{kg}$ & - & 200.00 & 250.00 & $2,470.00$ & - & $2,920.00$ \\
\hline $\begin{array}{l}\text { Branches from forest } \\
\text { clearance }\left(c_{11}\right)\end{array}$ & $\mathrm{kg}$ & $4,500.00$ & - & $16,250.00$ & $6,000.00$ & $8,500.00$ & $35,250.00$ \\
\hline $\begin{array}{l}\text { Wood waste from care } \\
\text { measures }\left(e_{3}\right)\end{array}$ & $\mathrm{kg}$ & $4,500.00$ & 200.00 & $16,500.00$ & $8,470.00$ & $8,500.00$ & $38,170.00$ \\
\hline Pig slurry $\left(c_{12}\right)$ & $\mathrm{m}^{3}$ & 134.90 & 109.00 & 111.00 & 48.00 & 50.00 & 452.90 \\
\hline Cattle slurry $\left(c_{13}\right)$ & $\mathrm{m}^{3}$ & $1,236.00$ & 502.00 & 981.00 & $2,365.00$ & $5,755.00$ & $10,839.00$ \\
\hline Slurry $\left(e_{4}\right)$ & $\mathrm{m}^{3}$ & $1,370.90$ & 611.00 & $1,092.00$ & $2,413.00$ & $5,805.00$ & $11,291.90$ \\
\hline Pig manure $\left(c_{14}\right)$ & $\mathrm{m}^{3}$ & 112.08 & 354.00 & 594.00 & 142.00 & 210.00 & $1,412.08$ \\
\hline Cattle manure $\left(c_{15}\right)$ & $\mathrm{m}^{3}$ & $2,967.75$ & $1,537.25$ & $3,470.00$ & $4,328.00$ & $2,810.50$ & $15,113.50$ \\
\hline Manure $\left(e_{5}\right)$ & $\mathrm{m}^{3}$ & $3,079.83$ & $1,891.25$ & $4,064.00$ & $4,470.00$ & $3,020.50$ & $16,525.58$ \\
\hline Poultry droppings $\left(c_{16}\right)$ & $\mathrm{kg}$ & $12,754.50$ & $31,371.75$ & $10,088.60$ & $5,650.00$ & $5,756.00$ & $65,620.85$ \\
\hline
\end{tabular}


Table 5. Energy content in individual types of waste biomass from agriculture by area groups of the surveyed farms.

\begin{tabular}{|c|c|c|c|c|c|c|}
\hline \multirow{2}{*}{$\begin{array}{c}\text { Types of waste biomass generated } \\
\text { on the surveyed farms }\end{array}$} & \multicolumn{5}{|c|}{$\begin{array}{c}\text { Energy content in individual waste biomass types [GJ-yr-1 }] \text {, classified by } \\
\text { area groups }\end{array}$} & \multirow{2}{*}{$\begin{array}{c}\text { Total } \\
{\left[\mathrm{GJ} \cdot \mathrm{yr}^{-1}\right]}\end{array}$} \\
\hline & $\begin{array}{c}\mathrm{I} \\
10.01-15.00 \\
\text { ha }\end{array}$ & $\begin{array}{c}\text { II } \\
15.01-20.00 \\
\text { ha }\end{array}$ & $\begin{array}{c}\text { III } \\
20.01-30.00 \\
\text { ha }\end{array}$ & $\begin{array}{c}\text { IV } \\
30.01-50.00 \\
\text { ha }\end{array}$ & $\begin{array}{c}\mathrm{V} \\
>50.00 \text { ha }\end{array}$ & \\
\hline Cereal straw & 448.91 & 564.73 & 315.74 & 983.82 & $3,441.68$ & $5,754.88$ \\
\hline Wood waste from care measures & 65.70 & 2.92 & 240.90 & 123.66 & 124.10 & 557.28 \\
\hline Slurry & 630.61 & 281.06 & 502.32 & $1,109.98$ & $2,670.30$ & $5,194.27$ \\
\hline Manure & $2,125.08$ & $1,304.96$ & $2,804.16$ & $3,084.30$ & $2,084.15$ & $11,402.65$ \\
\hline Poultry droppings & 205.35 & 505.09 & 162.43 & 90.97 & 92.67 & $1,056.50$ \\
\hline TOTAL: & $3,475.65$ & $2,658.76$ & $4,025.54$ & $5,392.73$ & $8,412.90$ & $23,965.58$ \\
\hline
\end{tabular}

In summary, energy carrier consumption in individual farm area groups is varied, but two energy carriers dominate (Fig. 3):

- Firewood (51.7\%) as a heat carrier;

- Diesel fuel (25.7\%) as a mechanical energy carrier.

Heat consumed on farms, both in the form of conventional (coal, coke, propane/butane gas) and quasiconventional carriers (firewood), can be substituted with heat produced from agricultural organic waste.

\section{Structure of Organic Waste Generated on the Surveyed Farms}

The data on the structure of organic waste from agriculture generated on the surveyed farms was broken down into individual area groups and presented synthetically in Table 4.

The data presented in Table 4 concern organic wastes that were not assigned for fertilizer, feed purposes, etc., and were real surpluses of organic by-products on the surveyed farms.

In summary, the main organic waste sources on farms in the province of Warmia and Mazury were droppings and cereal straw. However, all identified organic waste types were included in our analysis.

\section{Computations of the Energy Potential of Organic Waste from Agriculture}

The computations were performed in four steps:

- Step 1: Determination of the structure of the real energy consumption on the farms.

- Step 2: Determination of the value of the energy potential of waste biomass generated on the farms.

- Step 3: Determination of the value of the technical energy potential of waste biomass generated on the farms.

- Step 4: Determination of the degree of the substitution of the real energy consumption with energy from waste biomass generated on the farms.

Empirical data obtained during the questionnaire survey was used for the computations based on mathematical characteristics for determining energy potential of organic waste from agriculture.

Determining the Value of the Energy Potential of Waste Biomass from Agriculture without Taking

Energy Conversion Efficiency into Account

Energy potential is the total energy obtainable from organic waste generated on the farms. The computations

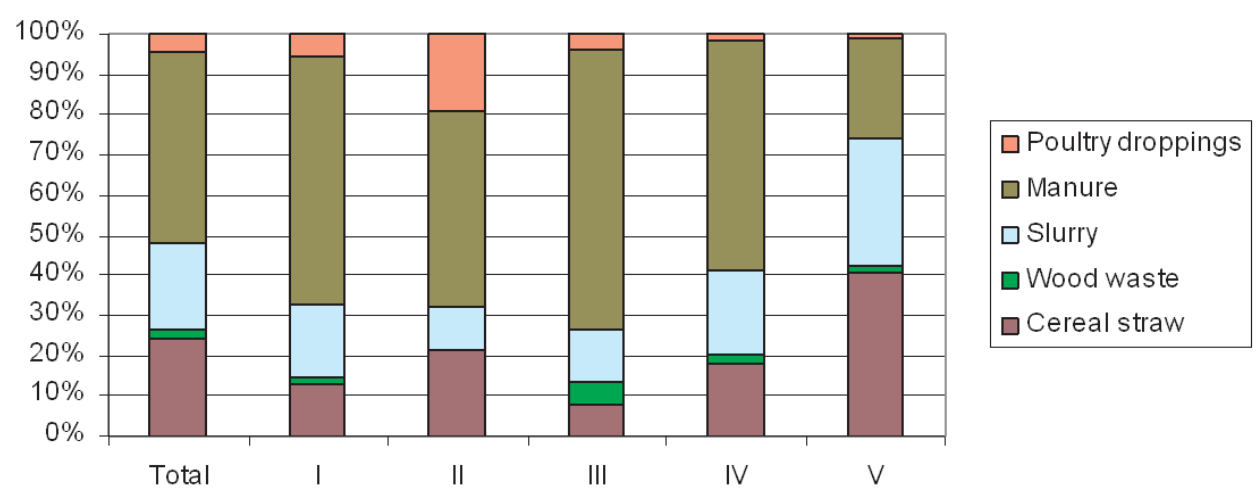

Fig. 4. Balance of energy contained in individual types of waste biomass from agriculture for the areas of groups: I - 10.01-15.00 ha, II - 15.01-20.00 ha, III - 20.01-30.00 ha, IV - 30.01-50.00 ha, V - more than 50.00 ha. 
Table 6. Computation results for the amount of energy from waste biomass on the surveyed farms using the listed production technologies.

\begin{tabular}{|c|c|c|}
\hline Energy production technology & $\begin{array}{c}\text { Total value for all the surveyed farms } \\
{\left[\mathrm{GJ} \cdot \mathrm{yr}^{-1}\right]}\end{array}$ & $\begin{array}{c}\text { Average per farm } \\
{\left[\mathrm{GJ} \cdot \mathrm{yr}^{-1} \cdot \mathrm{farm}^{-1}\right]}\end{array}$ \\
\hline $\begin{array}{c}\text { Electrical energy from the combustion of biogas from wet waste } \\
\text { biomass in a gas-fuelled cogeneration system - formula (14) }\end{array}$ & $6,183.9$ & 58.3 \\
\hline $\begin{array}{c}\text { Heat from the combustion of biogas from wet waste biomass in a } \\
\text { gas-fuelled cogeneration system - formula (17) }\end{array}$ & $8,834.2$ & 83.3 \\
\hline Heat from the combustion of solid waste biomass - formula (16) & $5,049.7$ & 47.6 \\
\hline \multicolumn{2}{|c|}{ TOTAL } & 189.2 \\
\hline
\end{tabular}

were performed separately for dry waste biomass and wet waste biomass.

The energy potential of dry waste biomass was computed using relationships (6), (7), and (8). Relationships (9), (10), (11), and (12) were used to compute the energy potential of wet waste biomass. The share of energy contained in individual waste biomass types in relation to the energy potential of waste biomass generated on the surveyed farms was determined from the above relationships. The computation results were shown in Table 5 and then illustrated in the column chart of Fig. 4. The first column of the chart shows the total balance of energy contained in individual types of waste biomass from agriculture. The next columns of the chart show the balances of the energy potential of waste biomass generated on the surveyed farms, broken down into individual area groups.

Based on the computation results for the share of energy contained in individual waste biomass types in the balance of the energy potential of waste biomass generated on the surveyed farms, it was found that:

- Groups I-IV had the highest share of energy contained in manure in the area by far.

- Energy contained in cereal straw had the highest share in the area of group $\mathrm{V}$.

\section{Determination of the Value of the Technical Energy Potential of Waste Biomass from Agriculture (Taking Energy Conversion Efficiency into Account)}

Technical energy potential is the part of energy potential that can be used and reduced by energy conversion efficiency. From among the technologies designed for energy production from waste biomass, only those were selected which the authors of this paper considered best suited to the current needs and conditions in Polish agriculture, which were also consistent with global clean energy production trends [73].
Combustion in a low-power water heater was selected for heat production from dry waste biomass, with a process efficiency at a mean level of $a_{e 8}^{2}=0.80$ [74]. This technology produces heat that can be used for a farm's own needs. A mathematical formula (16) was used to compute the amount of heat from dry waste biomass combustion in a low-power water heater.

The technology using biogas, which is obtained from the methane fermentation of wet biomass, was selected for energy production from wet waste biomass. The biogas was combusted in a CHP unit, which generated electrical energy and heat simultaneously. As reported in [75], the efficiency of electrical energy production by this method is $a_{e 9}^{3}=0.35$ and heat production efficiency was $a_{e 9}^{2}=0.50$. The following mathematical formulas were used to determine the amount of energy acquired from the combustion of biogas obtained from wet waste biomass in a cogeneration system:

- For computing the amount of electrical energy formula (14).

- For computing the amount of heat - formula (17).

The computation results are shown in Table 6 .

Determining the Substitution Degree of Real Energy Consumption on Farms with Energy from Organic Waste Generated by these Farms

The degree of primary energy substitution with energy from waste biomass was determined based on the methodology provided earlier. The average computation results for the degree of electrical energy $\left(\eta_{s}^{e l}\right)$ and heat substitution $\left(\eta_{s}^{\text {th }}\right)$ for individual farm area groups are presented in Table 7.

The data presented in Table 7 shows substantial surpluses of electrical energy producible from waste biomass $\left(\eta_{s}^{e l} \geq 100 \%\right)$ : from ca. $80 \%$ on the farms in the area group I to ca. $280 \%$ on the farms from the area

Table 7. Mean energy substitution degree in individual farm area groups.

\begin{tabular}{|c|c|c|c|c|c|c|}
\hline \multirow{2}{*}{$\begin{array}{c}\text { Energy substitution } \\
\text { degree }\end{array}$} & \multicolumn{5}{|c|}{ Farm area groups } & \multirow{2}{*}{ Average per farm } \\
\cline { 2 - 7 } & $\begin{array}{c}\text { I } \\
10.01-15.00 \text { ha }\end{array}$ & $\begin{array}{c}\text { II } \\
15.01-20.00 \text { ha }\end{array}$ & $\begin{array}{c}\text { III } \\
20.01-30.00 \text { ha }\end{array}$ & $\begin{array}{c}\text { IV } \\
30.01-50.00 \text { ha }\end{array}$ & $\begin{array}{c}\text { V } \\
>50.00 \text { ha }\end{array}$ & \\
\hline$\eta_{s}^{\text {el }}[\%]$ & 180.34 & 204.37 & 291.66 & 292.85 & 380.54 & 269.9 \\
\hline$\eta_{s}^{\text {th }}[\%]$ & 48.01 & 48.95 & 50.28 & 125.04 & 261.08 & 106.69 \\
\hline
\end{tabular}


group V. The occurrence of surpluses in heat production from waste biomass $\left(\eta_{s}^{\text {th }} \geq 100 \%\right)$ is much lower than for electrical energy production. It is particularly possible on the farms in the area of group V (ca. 160\%), and to a small degree on the farms from the area of group IV (ca. 25\%). On farms from the areas of groups I-III, around half of the demand for heat from conventional or quasi-conventional carriers can be covered with heat produced from waste biomass.

The computation results for the degree of electrical energy substitution $\left(\eta_{s}^{e l}\right)$ show that the mean value of the electrical energy substitution degree on a single farm is ca. $269.9 \%$, of which $100 \%$ of the electrical energy from organic waste is assigned to covering the farm's needs and the remaining $169.9 \%$ is an energy surplus that can be sold. In practice, $83 \%$ of the surveyed farms can produce electrical energy from their own organic waste, which will not only completely cover their own consumption, but will also bring additional profits from the management of surplus-produced electrical energy $\left(\eta_{s}^{e l} \geq 100 \%\right)$.

Heat consumption substitution capacities are much lower than for electrical energy. The computation results show that the average value of the heat substitution degree $\eta_{s}^{\text {th }}$ on a single farm is at ca. $106.69 \%$. In reality, the capacity for complete coverage of heat consumption from conventional or quasi-conventional carriers with heat from waste biomass and heat overproduction $\left(\eta_{s}^{\text {th }}>100 \%\right)$ exist on ca. $23 \%$ of the surveyed farms.

The presented computations show that the achievement of energy self-sufficiency of farms is possible above all for electrical energy production. Heat production from waste biomass gives much lower potential in this scope. However, considering the significantly high electric energy overproduction, actions can be taken to enable its use for heating purposes.

\section{Statistical Model for Determining the Unit Energy Potential of Organic Waste from Agriculture}

The statistical model will allow us to determine the relationship between farm size and the amount of energy that can be produced from organic waste during the year.

To determine the value of the unit energy potential $(U E P)$ of organic waste from agriculture $\left[\mathrm{GJ} \cdot \mathrm{ha}^{-1} \cdot \mathrm{yr}^{-1}\right]$, the form and parameters of the distribution of the random variable (UEP) were estimated by adopting the null hypothesis $\left(H_{0}\right)$ about the consistency of the empirical distribution with a normal distribution with the parameters $N(U E P ; s)$, where $U E P$ is the expected value of the unit energy potential of organic waste from agriculture and $S$ is standard deviation.

The consistency of the obtained empirical distributions was tested at a significance level of $\alpha=0.05$ using Pearson's $\chi^{2}$ test. It was found that the empirical distribution of the unit energy potential of organic waste [GJ.hat $\left.{ }^{-1} \mathrm{yr}^{-1}\right]$ on the surveyed farms was consistent with a log-normal distribution with the parameters $N(7.7436 ; 3.0403)$.

To examine the effect of farm area $(F A)$ on the UEP, a statistical analysis was performed by cubic curvilinear regression. It was checked whether the value of the unit energy potential of organic waste generated on a farm could be determined for a given farm area, following the principle that physical relationships most often occur in very simple mathematical forms $[42,76,77]$.

Statistical analysis of polynomial regression shows that the best approximation to the empirical data was obtained for two statistical models: cubic polynomials, expressed by relationship (20) for area groups I-IV and (21) for area group V:

$$
\begin{gathered}
U E P_{1}=-0.000035 F A^{3}-0.0005150 F A^{2} \\
-0.202764 F A+9.625177\left[\mathrm{GJ} \cdot \mathrm{ha}^{-1} \cdot \mathrm{yr}^{-1}\right] \\
\\
U E P_{1}=-0.000070 F A^{3}-0.021176 F A^{2} \\
+2.121141 F A-60.119134\left[\mathrm{GJ} \cdot \mathrm{ha}^{-1} \cdot \mathrm{yr}^{-1}\right]
\end{gathered}
$$

... where $F A$ is farm area [ha]. The results of the assessment of the fit of the obtained equations to the empirical data are shown in Table 8.

Based on the $U E P_{1}$ and $U E P_{2}$ statistical models, the total energy potential of organic waste from agriculture $(T E P)$ on individual farms can be determined:

- On farms with an area of 10.01-50 ha $\left(T E P_{1}\right)$ from relationship (22)

- On farms with an area higher than 50 ha from relationship $\left(T E P_{2}\right)(23)$

Table 8. Results of the assessment of the fit of Eqs. (20) and (21) to the empirical data.

\begin{tabular}{|c|c|c|c|c|}
\hline $\begin{array}{c}\text { Multiple correla- } \\
\text { tion coefficient }\end{array}$ & $\begin{array}{c}\text { Coefficient of } \\
\text { random variation }\end{array}$ & $\begin{array}{c}\text { Percentage of ex- } \\
\text { plained variation }\end{array}$ & $\begin{array}{c}\text { Standard deviation } \\
\text { of the residuals }\end{array}$ & Comments \\
\hline \multicolumn{7}{|c|}{ For Eq. (20) } & \multicolumn{5}{|c|}{ For Eq. (21) } & $\begin{array}{c}\text { The conducted stepwise variable elimination } \\
\text { procedure did not lead to a reduction } \\
\text { of the degree of the polynomial. }\end{array}$ \\
\hline 0.940 & 2.23 & $88.40 \%$ & 0.174 & $\begin{array}{c}\text { The conducted stepwise variable elimination } \\
\text { procedure did not lead to a reduction } \\
\text { of the degree of the polynomial. }\end{array}$ \\
\hline
\end{tabular}




$$
\begin{aligned}
& T E P_{1}=U E P_{1} \cdot F A\left[\mathrm{GJ} \cdot \mathrm{yr}^{-1}\right] \\
& T E P_{2}=U E P_{2} \cdot F A\left[\mathrm{GJ} \cdot \mathrm{yr}^{-1}\right]
\end{aligned}
$$

The computation results for $T E P_{1}$ and $T E P_{2}$ on the surveyed farms compared to the real $T E P^{*}$, resulting from the conducted survey, showed that:

- Only on ca. $7.5 \%$ of the farms did the real TEP $P^{*}$ values differ significantly from the values resulting from the theoretical estimation of energy potential $\left(T E P_{1}\right)$ from relationship (22).

- The $T E P_{2}$ values computed from relationship (23) did not show significant differences from $T E P^{*}$ in any case.

Therefore, it can be concluded that based on the statistical models $U E P_{1}$ and $U E P_{2}$, it is possible to estimate the approximate energy potential of organic waste from agriculture also on farms not covered by the survey, when only their area $(F A)$ is known. Hence, an attempt was also made to determine TEP on farms from the entire area of the province of Warmia and Mazury. The following actions were performed for this purpose:

1. The average farm area $\left(F A_{m}\right)$ for individual area groups was determined according to [78].

2. The $U E P_{1}$ and $U E P_{2}$ values were computed from relationships (20) and (21), using the values of the mean farm area $\left(F A_{m}\right)$ in the area groups I-IV and V, respectively. The $U E P_{m}$ values for the mean farm area in individual area groups were obtained.

3. The acquired $U E P_{m}$ values were used to compute the $T E P_{m}$ values for the mean farm area in a given area group using relationship (24).

4. Using the $T E P_{m}$ values, $T E P_{S U M}$ were computed for the total farm area in a given area group - relationship (25).

$$
\begin{gathered}
T E P_{m}=F A_{m} U E P_{m}\left[\mathrm{GJ} \cdot \mathrm{yr}^{-1}\right] \\
T E P_{S U M}=T E P_{m} n_{F}\left[\mathrm{GJ} \cdot \mathrm{yr}^{-1}\right]
\end{gathered}
$$

...where $n_{F}$ is the number of farms in a given area group.

The computation results are shown in Table 9.
The determined value of the energy potential of organic waste, $16.74 \mathrm{PJ} \cdot \mathrm{yr}^{-1}$, corresponds to energy obtained from the combustion of $730.000 \mathrm{Mg} \cdot \mathrm{yr}^{-1}$ of hard coal with a calorific value of $23 \mathrm{GJ} \cdot \mathrm{Mg}^{-1}$. We computed that the combustion of this quantity of hard coal would cause air emissions of substantial quantities of harmful chemical compounds:

- Carbon dioxide $\left(\mathrm{CO}_{2}\right) \rightarrow 2.197 \cdot 10^{6} \mathrm{Mg} \cdot \mathrm{yr}^{-1}$

- Sulphur dioxide $\left(\mathrm{SO}_{2}\right) \rightarrow 14.6 \cdot 10^{3} \mathrm{Mg} \cdot \mathrm{yr}^{-1}$

- Nitrogen dioxide $\left(\mathrm{NO}_{2}\right) \rightarrow 1.6 \cdot 10^{3} \mathrm{Mg} \cdot \mathrm{yr}^{-1}$

The environmental emissions of the harmful substances presented above can be substantially reduced by hard coal substitution with biomass in energy production. As a result of hard coal substitution with biomass, the emission values for the above mentioned pollutants will cause reduction of the emissions of these pollutants in the following ranges [79]:

- $100 \%$ for $\mathrm{CO}_{2}$, representing a reduction by $2.197 \cdot 10^{6}$ $\mathrm{Mg} \cdot \mathrm{yr}^{-1}$,

- $97 \%$ for $\mathrm{SO}_{2}$, representing a reduction by $14.16 \cdot 10^{3}$ $\mathrm{Mg} \cdot \mathrm{yr}^{-1}$,

- $80 \%$ for $\mathrm{NO}_{2}$, representing a reduction by $1.28 \cdot 10^{3}$ $\mathrm{Mg} \cdot \mathrm{yr}^{-1}$.

\section{Discussion and Conclusions}

A statistical model was developed consisting of two relationships $-U E P_{1}$ and $U E P_{2}$, allowing the unit energy potential of organic waste from a given farm to be estimated, depending on its area. This model allowed the total energy potential of organic waste from agriculture $\left(T E P_{1}\right.$ and $\left.T E P_{2}\right)$ to be determined.

In the province of Warmia and Mazury the total energy potential of organic waste from agriculture $T E P_{S U M}$ amounts to $16.74 \mathrm{PJ} \cdot \mathrm{yr}^{-1}$, which gives ca. $18.5 \mathrm{GJ} \cdot \mathrm{ha}^{-1} \cdot \mathrm{yr}^{-1}$. The analysis for the share of the amount of energy contained in individual types of organic waste from agriculture shows that the share of energy contained

\begin{tabular}{|c|c|c|c|c|c|}
\hline Farm area group & $\begin{array}{c}\text { I } \\
10.01-15.00 \\
\text { ha }\end{array}$ & $\begin{array}{c}\text { II } \\
15.01-20.00 \\
\text { ha }\end{array}$ & $\begin{array}{c}\text { III } \\
20.01-30.00 \\
\text { ha }\end{array}$ & $\begin{array}{c}\text { IV } \\
30.01- \\
50.00 \text { ha }\end{array}$ & $\begin{array}{c}\mathrm{V} \\
>50.00 \text { ha }\end{array}$ \\
\hline$F A_{m}[\mathrm{ha}]$ & 12.54 & 17.29 & 24.33 & 37.74 & 166.54 \\
\hline $\begin{array}{l}\text { Total number of farms in a given area group } \\
\qquad n_{F}[78]\end{array}$ & $7,675.00$ & $4,807.00$ & $4,851.00$ & $3,843.00$ & $2,768.00$ \\
\hline $\begin{array}{l}\text { Total farm area in a given area group } \\
\qquad \sum F A[\mathrm{ha}][78]\end{array}$ & $96,230.00$ & $83,092.00$ & $118,010.00$ & $145,025.00$ & $460,986.00$ \\
\hline$U E P_{m}\left[\mathrm{GJ} \cdot \mathrm{ha}^{-1} \cdot \mathrm{yr}^{-1}\right]$ & 7.82 & 7.48 & 7.24 & 7.43 & 29.14 \\
\hline$T E P_{m}\left[\mathrm{GJ} \cdot \mathrm{yr}^{-1}\right]$ & 98.10 & 129.30 & 176.06 & 280.28 & $4,852.98$ \\
\hline$T E P_{S U M}\left[\mathrm{GJ} \cdot \mathrm{yr}^{-1}\right]$ & $752,840.44$ & $621,365.59$ & $853,966.58$ & $1,077,054.25$ & $13,433,036.46$ \\
\hline TOTAL $\sum T E P_{S U M}:$ & \multicolumn{5}{|c|}{$16,738,263.32 \mathrm{GJ} \cdot \mathrm{yr}^{-1}=16.74 \mathrm{PJ} \cdot \mathrm{yr}^{-1}$} \\
\hline
\end{tabular}
in manure is by far the highest $(49.06-69.61 \%)$ in the

Table 9. Computation results for the value of the unit (UEP) and total (TEP) energy potential of waste biomass on farms in the province of Warmia and Mazury. 
10.01-50.00 ha area groups, and the share of energy contained in cereal straw is highest $(40.88 \%)$ in the $>50.00$ ha area group.

The electrical energy substitution degree $\left(\eta_{s}^{e l}\right)$ and the heat substitution degree $\left(\eta_{s}^{\text {th }}\right)$ were determined for the surveyed farms. It was established that the mean value of the electrical energy substitution degree in individual farm area groups was from ca. $180 \%$ on the farms of area group I to ca. $380 \%$ on farms from the area of group V. Such results $\left(\eta_{s}^{e l} \geq 100 \%\right)$ show the high potential for achievement of energy self-sufficiency by farms. The mean heat substitution degree values for individual farm area groups indicate that significantly high heat surpluses will occur only on the farms in the area of group $\mathrm{V}$ $\left(\eta_{s}^{\text {th }} \approx 260 \%\right.$ ) and slightly high heat surpluses will occur on farms in the area of group IV ( $\left.\eta_{s}^{\text {th }} \approx 125 \%\right)$. On the farms from the area of groups I-III, around half of the demand for heat from conventional or quasi-conventional carriers can be covered with heat produced from waste biomass because in these area groups $\eta_{s}^{\text {th }} \approx 50 \%$. The mean value of the degree of primary energy substitution with energy from waste biomass, without being broken down into area groups, is: $\eta_{s}^{e l}=269.9 \%, \eta_{s}^{\text {th }}=106.69 \%$.

Our computations show that the annual energy potential of organic waste $\left(16.74 \mathrm{PJ} \cdot \mathrm{yr}^{-1}\right)$ is equivalent to $730.000 \mathrm{Mg}$ of hard coal. Substitution of this quantity of coal with organic waste will reduce air emissions by:

- $2.197 \cdot 10^{6} \mathrm{Mg} \mathrm{CO}_{2} \cdot \mathrm{yr}^{-1}$

- $14.16 \cdot 10^{3} \mathrm{Mg} \mathrm{SO}_{2} \cdot \mathrm{yr}^{-1}$

- $1.28 \cdot 10^{3} \mathrm{Mg} \mathrm{NO}_{2} \cdot \mathrm{yr}^{-1}$

The conducted research presented in this paper proves that the energy potential contained in organic waste from agriculture is significant and is going unnoticed by farmers and decision-makers. Focusing efforts on energy crop production to meet the demand for renewable fuels obscures the picture that emerges from the conducted research: the level of renewable energy from agricultural organic waste alone allows a realistic assessment of the energy self-sufficiency of farms, as we considered only those waste groups that cannot be agriculturally managed.

\section{References}

1. DEMIRBAS A.H., DEMIRBAS I. Importance of rural bioenergy for developing countries. Energ. Convers. Manage., 48, 2386, 2007.

2. McKENDRY P. Energy production from biomass (part 1): Overview of biomass (Review). Bioresource Technol. 83 (1), 37, 2002.

3. ADAMS E. E. Fossil fuel use pushes carbon dioxide emissions into dangerous territory [Internet] 2013. [cited 2013 Nov 20]. Available from: http://www.earth-policy.org/ indicators/C52/carbon_emissions_2013

4. IPCC. Climate change 2001: impacts, adaptation and vulnerability. Report of the working group II. UK: Cambridge University Press p. 967, 2001.

5. IPCC. Climate change 2007: impacts, adaptation and vulnerability. Summary for policymakers and technical summary, WG II contribution to the AR4. UK: Cambridge University Press p. 93, 2007.
6. MONTAGNINI F., NAIR P.K.R. Carbon sequestration: an underexploited environmental benefit of agroforestry systems. Agroforest. Syst. 61, 281, 2004.

7. GREENE C.H., PERSHING A.J. Climate-driven sea change. Science 315, 1084, 2007.

8. PRATHER M., EHHALT D., DENTENER F., DERWENT R., DLUGOKENCKY E., et al. Atmospheric chemistry and greenhouse gases. In: HOUGHTON J. T., DING Y., GRIGGS D.J., NOGUER M., VAN DER LINDEN P.J., et al., editors. Climate change 2001: the scientific basis. Cambridge University Press 239, 2001.

9. HALL D.O., ROSILLO C.F., WILLIAMS R.H., WOODS J. Biomass for energy: supply prospects. In: JOHANSSON B.J., KELLY H., REDDY A.K.N., WILLIAM R.H., editors. Renewable energy: sources for fuels and electricity. Washington, DC: Island Press; 1993.

10. DHILLON R.S., VON WUEHLISCH G. Mitigation of global warming through renewable biomass. Biomass Bioenerg. 48, 75, 2013.

11. ZAMORANO M., POPOV V., RODRÍGUEZ M.L., GARCÍA-MARAVER A. A comparative study of quality properties of pelletized agricultural and forestry logging residues. Renew. Energ. 36 (11), 3133, 2011.

12. MONFORTI F., BÓDIS K., SCARLAT N., DALLEMAND J.F. The possible contribution of agricultural crop residues to renewable energy targets in Europe: A spatially explicit study. Renew. Sust. Energ. Rev. 19, 666, 2013.

13. Biofuel production technologies: status, prospects and implications for trade and development. United Nations Conference on Trade and Development, New York and Geneva, 1, 2008.

14. CARRIQUIRY M., DU X., TIMILSINA G. Secondgeneration biofuels: Economics and policies. The Word Bank Development Research Group Environment and Energy Team, 1, 2010.

15. EISENTRAUT A. Sustainable production of secondgeneration biofuels potential and perspectives in major economies and developing countries. IEA, 1, 2010.

16. SEARCHINGER T., HEIMLICH R. Avoiding Bioenergy Competition for Food Crops and Land. Working Paper, Installment 9 of Creating a Sustainable Food Future. Washington, DC: World Resources Institute, 2015.

17. BENTSEN N.S., FELBY C., THORSEN B.J. Agricultural residue production and potentials for energy and materials services. Prog. Energ. Combust. Sci. 40, 59, 2014.

18. DOORNBOSCH R., STEENBLIK R. Biofuels: is the cure worse than the disease? Revista Virtual REDESMA 2 (2), 2008.

19. HABERL H., BERINGER T., BHATTACHARYA S.C., ERB K.-H., HOOGWIJK M. The global technical potential of bio-energy in 2050 considering sustainability constraints. Curr. Opin. Environ. Sustain. 2, 394, 2010.

20. HOOGWIJK M., FAAIJ A., VAN DEN BROEK R., BERNDES G., GIELEN D., TURKENBURG W. Exploration of the ranges of the global potential of biomass for energy. Biomass Bioenerg. 25, 119, 2003.

21. SMEETS E., FAAIJ A., LEWANDOWSKI I., TURKENBURG W. A bottom-up assessment and review of global bio-energy potentials to 2050. Prog. Energ. Combust. Sci. 33, 56, 2007.

22. BIERANOWSKI J., OLKOWSKI T. Concept for substitution of primary energy by renewable energy obtained from waste biomass in a selected agricultural farm. Agric. Eng. 7 (95), 23, 2007 [in Polish].

23. KIMBALL B.A., KOBAYASHI K., BINDI M. Responses of agricultural crops to free-air $\mathrm{CO}_{2}$ enrichment. Adv. Agron. 77, 293, 2002. 
24. ROOT T.L., PRICE J.T., HALL K.R., SCHNEIDER S.H., ROSENZWEIG C., POUNDS J.A. Fingerprints of global warming on wild animals and plants. Nature 421, 57, 2003.

25. RODHE L.K.K., ABUBAKER J., ASCUE J., PELL M., NORDBERG A. Greenhouse gas emissions from pig slurry during storage and after field application in northern European conditions. Biosystems Eng. 113 (4), 379, 2012.

26. VINTERBÄCK J. Pellets 2002: The first world conference on pellets. Biomass Bioenerg. 27, 513, 2004.

27. ŻUK D., RODE H. A concept of an agricultural bio-waste processing system in the Oporów Commune. II International Scientific and Technology Conference "Recycling Problems" SGGW, PW, Rogów 20-21 November 2002 [In Polish].

28. LIPSKI R., ORLIŃSKI S., TOKARSKI M. Energy utilization of biomass based on a straw-heated boiler-room in Frombork. Motorization and Power Industry in Agriculture 8A, 202, 2006 [In Polish]

29. SOŁOWIEJ P. Qualitative and quantitative analysis of waste from agricultural farm on the example of a community. Agric. Eng. 1 (61), 155, 2005 [In Polish].

30. ERICSSON K., NILSSON L.J. Assessment of the potential biomass supply in Europe using a resource-focused approach. Biomass Bioenerg. 30, 1, 2006.

31. SCARLAT N., MARTINOV M., DALLEMAND J.F. Assessment of the availability of agricultural crop residues in the European Union: Potential and limitations for bioenergy use. Waste Manage. 30 (10), 1889, 2010

32. PANOUTSOU C., ELEFTHERIADIS J., NIKOLAOU A. Biomass supply in EU27 from 2010 to 2030. Energ. Policy 37, 5675, 2009.

33. PASKA J., SAŁEK M., SURMA T. Current status and perspectives of renewable energy sources in Poland. Renew. Sust. Energ. Rev. 13, 142, 2009.

34. IGLIŃSKI B., BUCZKOWSKI R., IGLIŃSKA A., CICHOSZ M., PIECHOTA G., KUJAWSKI W. Agricultural biogas plants in Poland: Investment process, economical and environmental aspects, biogas potential. Renew. Sust. Energ. Rev. 16, 4890, 2012.

35. ANGELIDAKI I., ELLEGAARD L. Codigestion of manure and organic wastes in centralized biogas plants. Appl. Biochem. Biotech. 109, 95, 2003.

36. DACH J., ZBYTEK Z., PILARSKI K., ADAMSKI M. Research on waste usage efficiency from biofuel production as a substrate in a biogas plant. Agric. Hortic. For Eng. 6, 5, 2009 [In Polish].

37. ZHENG Y.H., LI Z.F., FENG S.F., LUCAS M., WU G.L., LI Y., LI C.H., JIANG G.M. Biomass energy utilization in rural areas may contribute to alleviating the energy crisis and global warming: A case study in a typical agro-village of Shandong, China. Renew. Sust. Energ. Rev. 14, 3132, 2010.

38. KOCAMAN I., KONUKCU F., OZTURK G. Meaures to protect environmental problems ceused by animalwastes in rural sttelment areas: A case study from Western Turkey. J. Anim. Vet. Adv. 10 (12), 1536, 2011.

39. GLASZCZKA A., WARDAL W.J., ROMANIUK W., DOMASIEWICZ T. Agro-bio-gas plants. MULTICO Publishing Board, Warsaw; 2010 [in Polish].

40. DE WIT M., FAAIJ A. European biomass resource potential and costs. Biomass Bioenerg. 34, 188, 2010.

41. PABIS S. Methodology and methods of empirical sciences. PWN. Warsaw; 1985 [In Polish].

42. BIERANOWSKI J., PIECHOCKI J. Eco-energy program of the province of Warmia and Mazury for 2005-2010. Issued by the Marshal's Office of the province of Warmia and Mazury, Olsztyn, 2005 [In Polish].
43. CEMPEL C. Systems theory, systems engineering principles and applications of system thinking [Internet]. 2008. [cited 2013 Dec 5]. Available from: http://neur.am.put. poznan.pl.e-scripts

44. BLANCHARD B.S., FABRYCKY W.J. Systems Engineering and Analysis. New York: Prentice Hall; 1990.

45. WAELCHLI F. Eleven Theses of General System Theory (GST). Syst. Res. 4 (9), 3, 1992.

46. WINIWARTER P., CEMPEL C. Life Symptoms - the Behavior of Open Systems with Limited Energy Dissipation Capacity and Evolution, Syst. Res. 4 (3), 9, 1992.

47. BIERANOWSKI J. Model of a maintenance system for selected machinery in the food processing industry. Agric. Eng. 1 (43), 9, 2003 [In Polish].

48. BIERANOWSKI J., KLONOWSKI A. The model of an associated energy source in the food processing industry. Agric. Eng. 6 (66), 33, 2005 [In Polish].

49. BARTON R.F. A Primer on Simulation and Gaming. New Jersey: Prentice Hall; 1970.

50. PABIS S. Methodological basis of IT system modelling. IV National symposium on exploitation of technical equipment. T.2., PPT, Katowice; 1977 [in Polish].

51. JAŹWIŃSKI J., PABIS S., WIEREMIEJCZYK W. Technical system simulation principles. Simulation testing methods for reliability of technical systems. 1. Materials for "Winter school -75" Jaszowiec; 1975 [In Polish].

52. Statistical Office in Olsztyn. Warminsko-mazurskie voivodship in figures 2013 [Internet]. Olsztyn; 2013. [cited 2013 Dec 4]. Available from: http://www.stat.gov.pl/cps/rde/ xbcr/olsz/ASSETS_Warm_mazur_w_liczbach_2013.pdf

53. Google Maps [Internet]. 2013. (access 27.10.2013). [cited 2013 Oct 27]. Available from: https://maps. google.pl/maps? q=wojew $\%$ C $3 \%$ B 3 dztwo + warm i\% C5\%84sko-mazurskie \&ie $=U$ TF $-8 \&$ hq $=\&$ hnea $\mathrm{r}=0 \times 46$ e $20 \mathrm{~d} 3$ eacc 5 ae $17: 0 \times 1020$ e 32 ad 0 ec 0 f0, wa rmi\%C5\%84sko-mazurskie \& gl=pl\&ei=QEptUonrPIK3hAeUjIGAAg\&ved $=0 \mathrm{CHsQtgM}$

54. Statistical Office in Olsztyn. Characteristics of agricultural farms in the province of Warmia and Mazury. Agricultural census 2010 [Internet]. Olsztyn; 2012. [in Polish] [cited 2013 Dec 4]. Available from: http://www.stat.gov.pl/cps/rde/ xbcr/olsz/ASSETS_charakterystyka_PSR_2010.pdf

55. KUKUŁA K. Research on the agrarian structure in Poland in spatial grasp. Acta Scientiarum Polonorum, seria Oeconomia 6 (4), 19, 2007 [in Polish].

56. PASZKOWSKI S. The impact of acreage and spatial differentiation of the farms on economic activity and incomes from farming in Poland. Acta Scientiarum Polonorum, seria Oeconomia 6 (2), 97, 2007 [In Polish].

57. PIĘTA P. Farmers' pensions as an instrument of agrarian structure changes in Poland. Acta Scientiarum Polonorum, seria Oeconomia 6 (4), 39, 2007 [in Polish].

58. IGNATCZYK W., CHROMIŃSKA M. Statistics. Theory and application. Editing Board of the Higher Banking School. Poznań, 2004 [In Polish].

59. STANISZ A. Straightforward course in statistics based on STATISTICA PL based on medical examples. StatSoft Polska, Kraków, 2001 [In Polish].

60. SHANNON R. E. Systems simulation. New Jersey: Prentice Hall; 1975.

61. BIERANOWSKI J. Selection criteria of functional assemblies in the construction aspects of a tetra-pack machine abstract model. Agric. Eng. 1 (61), 33, 2005. [In Polish]

62. PILCH T., BAUMAN T. Pedagogic research principles. Quantitative and qualitative strategies, $2^{\text {nd }}$ ed.; "Żak" Academic Publishing Board: Warsaw, 2001 [In Polish]. 
63. ŁOBOCKI M. Methods and techniques of pedagogic research. "IMPULS" Publishing Board: Kraków, 2003 [in Polish]

64. ZACZYŃSKI W. Teacher's research work, 5th ed.; Warsaw, 1997 [In Polish].

65. MASZKE A. W. Methods and techniques of pedagogic research. Publishing Board of the Rzeszów University: Rzeszów, 2008. [In Polish].

66. DEMIDOWICZ G., DEPUTAT T., GÓRSKI T., ZALIWSKI A., WRÓBLEWSKA E. Numerical map of length of vegetation period. IUNG Puławy 1998.

67. Central Statistical Office of Poland. Prices of agricultural products - January - December 2005.

68. Central Statistical Office of Poland. Prices of agricultural products - January - December 2006.

69. Central Statistical Office of Poland. Prices of agricultural products - January - December 2007.

70. Central Statistical Office of Poland. Prices of agricultural products - January - December 2008.

71. Central Statistical Office of Poland. Prices of agricultural products - January - December 2009.

72. Central Statistical Office of Poland. Prices of agricultural products - January - December 2010

73. NILSSON L.J., PISAREK M., BURIAK J., ONISZKPOPŁAWSKA A., BUĆKO P., ERICSSON K., JAWORSKI
Ł. Energy policy and the role of bioenergy in Poland. Energ. Policy 34, 2263, 2006.

74. BIERANOWSKI J., OLKOWSKI T. Comparison of combustion gas emission by low power boilers fired by biomass obtained from wood - pellets. Tech. Sci. 12, 9, 2009.

75. KARPENSTEIN-MACHAN M. Sustainable cultivation concepts for domestic energy production from biomass. Crit. Rev. Plant. Sci. 20 (1), 1, 2001.

76. GAWĘCKI J., WAGNER W. Methodological bases of experimental research in nutritional and food sciences . PWN Warszawa - Poznań, 1984 [In Polish].

77. PRZESTALSKI S. Elements of physics, biophysics and agriphysics. Publishing Board of Wrocław University: Wrocław, 2001 [In Polish].

78. Statistical Office in Olsztyn. Characteristics of agricultural farms in the province of Warmia and Mazury. Agricultural census 2010 [Internet]. Olsztyn, 2012. [In Polish] [cited 2013 Dec 4]. Available from: http://www.stat.gov.pl/cps/rde/ xbcr/olsz/ASSETS_charakterystyka_PSR_2010.pdf

79. KUBICA K. Biomass combustion and co-combustion with coal - techniques, benefits and barriers [Internet]. Institute for Chemical Processing of Coal: Zabrze 2004. [In Polish]. [cited 2015 Apr 21]. Available from: http://conbiot.ichpw. zabrze.pl/25_Spalanie_biomasy_i_jej_wspo3spalanie_z_ weglem.pdf 